\title{
The role of ciliates within the microbial food web in the eutrophicated part of Kaštela Bay (middle Adriatic Sea)
}

\author{
NATALIA BOJANIĆ ${ }^{1}$, MLADEN ŠOLIĆ ${ }^{1}$, NADA KRSTULOVIĆ ${ }^{1}$, STEFANIJA \\ ŠESTANOVIĆ ${ }^{1}$, ŽIVANA NINČEVIĆ GLADAN ${ }^{1}$, IVONA MARASOVIĆ ${ }^{1}$ \\ and IGOR BRAUTOVIĆ ${ }^{2}$
}

\begin{abstract}
${ }^{1}$ Institute of Oceanography and Fisheries, Šetalište I. Meštrovića 63, 21000 Split, Croatia. E-mail: bojanic@izor.hr ${ }^{2}$ University of Dubrovnik, Institute of Marine and Coastal Research, Kneza Damjana Jude 12, 20001 Dubrovnik, Croatia
\end{abstract}

SUMMARY: Interactions among phytoplankton, bacterioplankton, heterotrophic nanoflagellates (HNF), ciliated protozoa and copepod nauplii were studied in the eutrophicated part of Kaštela Bay from May 1998 to November 1999. Special emphasis was placed on relationships between size categories of nonloricate ciliates (NLC) and other microbial food web components. Biomasses of phytoplankton and bacteria were primarily influenced by abiotic parameters. Temperature indirectly controlled variation in HNF biomass through the changes in biomass of bacteria and the smaller phytoplankton fraction. Besides HNF, bacterial biomass was affected by the NLC $<10^{3} \mu \mathrm{m}^{3}$ (Cell Length $<20 \mu \mathrm{m}$ ). A small NLC size category $\left(<10^{4} \mu \mathrm{m}^{3}, \mathrm{CL}<40 \mu \mathrm{m}\right)$ could limit the growth of $\mathrm{HNF}$ as they compete for bacteria and as a result of direct grazing. Nonloricate ciliates $>10^{4} \mu \mathrm{m}^{3}(\mathrm{CL}>40 \mu \mathrm{m})$ had a strong mutual correlation and they seemed to be controlling the microphytoplankton fraction. During the colder part of the year, HNF abundance was regulated by ciliate grazing. The high impact of ciliates in summer 1998 could have been influenced by the taxonomic composition of the phytoplankton community changing, as well as the higher eutrophication level in the study area. Predation by copepod nauplii on ciliates and carbon transfer to higher trophic levels appear to be of relative importance only in the period when they are most abundant. This paper outlines the dominant relationships within the microbial food web and suggests that a significant amount of bacterial production, phytoplankton and HNF biomass could be transferred to higher trophic levels through the microbial food web.

Keywords: ciliated protozoa, biotic factors, abiotic factors, microbial food web, Adriatic Sea.

RESUMEN: El ROL DE LOS CILIADOS EN LA RED TRÓFICA MICROBIANA DE LA ZONA EUTRÓFICA DE LA BAHÍA DE KAŠTELA (ADRIÁTICO CENTRAL). - Las interacciones entre fitoplancton, bacterioplancton, nanoflagelados heterótrofos (HNF), ciliados y nauplios de copepodos fueron estudiadas en una zona eutrófica de la bahía de Kaštela desde Mayo de 1998 hasta Noviembre de 1999. Se dedicó una atención especial a la relación entre distintas clases de tamaños de ciliados no loricados (NLC) y otros componentes de las redes tróficas microbianas. Las biomasas de fitoplancton y bacterioplancton estaban principalmente influenciadas por parámentros abióticos. La temperatura de forma indirecta controlaba la variación de la biomasa de HNF, a través de cambios en la biomasa bacteriana y de la fracción de menor tamaño de fitoplancton. Aparte de los nanoflagelados heterótrofos, la biomasa bacteriana estaba afectada por los NLC $<10^{3} \mu \mathrm{m}^{3}$, longitud celular $<20 \mu \mathrm{m}$ ). Pequeños NLC (de una clase de tamaño $<10^{4} \mu \mathrm{m}^{3}$, LC $<40 \mu \mathrm{m}$ ) podrían limitar el crecimiento de los HNF compitiendo por las bacterias y también por depredación directa sobre ellos. Los NLC $>10^{4} \mu \mathrm{m}^{3}$ (LC>40 $\mu \mathrm{m}$ ) estaban fuertemente correlacionados con los anteriores y presuntamente son los que controlan la fracción de fitoplancton. Durante el período frío del año, la abundancia de HNF estaba regulada por la depredación de ciliados. El importante impacto de los ciliados en verano de 1998 podría estar influenciado por cambios en la composición taxonómica de la comunidad de fitoplancton, como también cuanto mas alto era el factor de eutrofización del área investigada. La depredación por nauplios de copépodo sobre ciliados y su transferencia de carbono a niveles tróficos superiores, parece ser de relativa importancia sólo en el período donde se alcanzan las máximas abundancias. Este trabajo incide en las relaciones que dominan dentro de las redes tróficas microbianas y sugiere que una parte importante de la producción bacteriana, de la biomasa de fitoplancton y HNF podría ser transferida a niveles tróficos superiores a través de las redes tróficas microbianas

Palabras clave: protistas ciliados, factores bióticos y abióticos, redes tróficas microbianas, mar Adriático. 


\section{INTRODUCTION}

Two regulation mechanisms of organism abundance and biomass are generally recognised in planktonic ecosystems: control by resources (bottom-up) and control by predators (top-down control). Recent studies suggest that both mechanisms are equally important (Kivi et al., 1996). The bottom-up control of ciliates is conditioned by the biomasses of phytoplankton, bacterioplankton and heterotrophic nanoflagellates (HNF) (Hagström et al., 1988; Rassoulzadegan et al., 1988; Šolić and Krstulović, 1995). In addition, ciliates are controlled by zooplankton predation (Paffenhöfer, 1998; Pitta et al., 1998). Furthermore, the relationships between the members of the plankton assemblage could be indirect, via trophic cascade. Ciliates as the main HNF consumers decrease the HNF abundance and their grazing impact on bacteria (Conover, 1982; Šolić and Krstulović, 1994; Sherr and Sherr, 2002; Urrutxurtu et al., 2003), which in turn increases the bacterial biomass. Although several studies have dealt with trophic relationships within the microbial food web (Sanders et al., 1989; Verity and Smetacek, 1996; Rodríguez et al., 2000), information about microbial interactions is still very limited.

Previous studies in Kaštela Bay showed the microzooplankton to be an important zooplankton fraction, characterised by high biomass and intensive population dynamics (Bojanić, 2001; Bojanić et al., 2001). One approach to studying trophic relations and their role in the cycling of organic matter is to analyse the temporal variability of planktonic components (Rodríguez et al., 2000). Therefore, in the present study we focused on the food linkage between phytoplankton, bacteria, HNF and ciliates and followed seasonal changes in abundance and biomass of these organisms. Our earlier research in Kaštela Bay indicated some relationships within the food web and showed nonloricate ciliates to be a crucial factor of topdown control, particularly on $<10 \mu$ m phytoplankton and HNF (Bojanic et al., 2005). The main aims of this paper were to examine which relationships within the microbial food web were predominate, as well as which of the investigated parameters had direct or indirect connections. We also investigated the seasonal fluctuations of copepod nauplii in order to analyse their effect on the microbial food web.

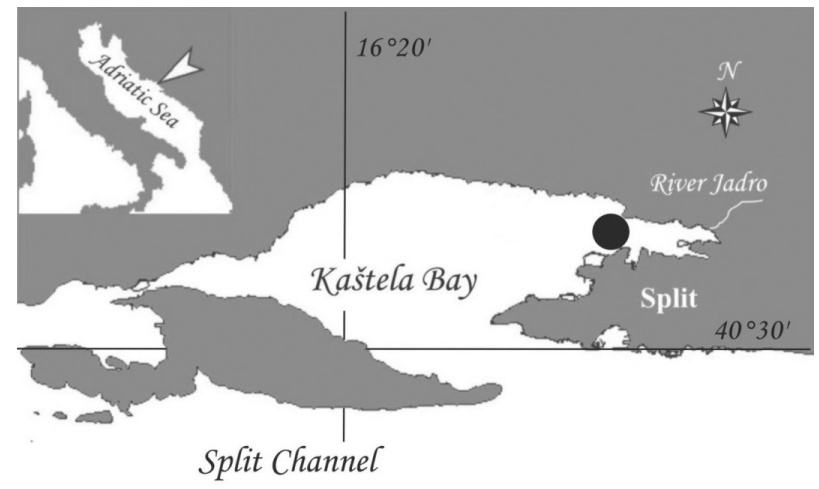

FIG. 1. - Location of the sampling station (Vranjic) in the Kaštela Bay.

\section{MATERIALS AND METHODS}

\section{Study area}

Samples were collected at one station (Vranjic) located in the eastern part of Kaštela Bay (4331.9'N 16²7.2'E) (Fig. 1). The most important source of fresh water in this region is the river Jadro, which discharges into the bay near the sampling station. The discharge of several submarine springs and Pantan brook located along the south-eastern and north-western part of the bay, are of lower intensity. The area of the bay studied also receives large quantities of untreated municipal and industrial effluents. The strong land and anthropogenic impacts result in large oscillations in the hydrographic parameters (Zore-Armanda, 1980).

\section{Sampling methods and measurement techniques}

Water samples were collected on a monthly basis, at $5 \mathrm{~m}$ depth intervals between the surface and bottom $(17 \mathrm{~m})$ with 51 Niskin bottles, from May 1998 to November 1999. Organisms were preserved in buffered formaldehyde with final concentrations of $2.5 \%$. In the laboratory microzooplankton samples were sedimented (Utermöhl, 1958) for $48 \mathrm{~h}$ in plastic containers and decanted down to a volume of 21 . This volume was poured into a cylinder and sedimented for the following $48 \mathrm{~h}$. The excess volume was then reduced to $200 \mathrm{ml}$. Prior to microscopic analysis, this volume was reduced to $20 \mathrm{ml}$. These microzooplankton samples were used for counting tintinnids and copepod nauplii. Counting and species identification were performed with an inverted microscope "Olympus" CK40 at magnifications of X100 and X400. 
For a quantitative analysis of nonloricate ciliates, we used a separate $100 \mathrm{ml}$ aliquot volume taken from the initial 51 and counting was done under X200 magnification. The organisms were fixed with formaldehyde in the same way as tintinnids. We chose this fixative because it does not stain the detritus (Fonda Umani and Beran, 2003), which can be abundant in the eutrophicated area of Kaštela Bay. Since formaldehyde causes cell loss (Leakey et al., 1994), our data may be somewhat underestimated.

The biovolume of nonloricates was calculated by comparing the shape of the plasmatic body of each individual organism to one or more geometrical bodies (Edler, 1979). After being measured they were divided into four size categories: I - Volume $<10^{3}$, Cell Length $<20 \mu \mathrm{m}$; II $-\mathrm{V} 10^{3}-10^{4} \mu \mathrm{m}^{3}$, CL 20-40 $\mu \mathrm{m}$; III - V 104-105 $\mu \mathrm{m}^{3}$, CL 40-80 $\mu \mathrm{m}$; IV $\mathrm{V}>10^{5} \mu \mathrm{m}^{3}, \mathrm{CL}>80 \mu \mathrm{m}$. The biovolume of tintinnids was estimated separately for each species by measuring the linear dimensions of the lorica. Empty loricas were also considered in the calculation. The geometrical method was also applied for determining the biovolume of copepod nauplii. Their biovolume was calculated according to the modified formula for rotifers (Ruttner-Kolisko, 1977). The following conversion factors were used to transform these biovolumes into carbon biomass values: for nonloricate ciliates $0.14 \mathrm{pgC} \mu \mathrm{m}^{-3}$ (Putt and Stoecker, 1989), for copepod nauplii $0.08 \mathrm{pgC}$ $\mu \mathrm{m}^{-3}$ (Beers and Stewart, 1970; Monti and Fonda Umani, 1999) and 444.5 pgC + (lorica volume in $\mu \mathrm{m}^{-3} \times 0.053 \mathrm{pgC}$ ) per cell for tintinnids (Verity and Langdon, 1984).

Samples for bacterial and heterotrophic nanoflagellate (HNF) counts and chlorophyll $a$ concentration were collected at the same depths parallel to microzooplankton sampling. Chlorophyll $a$ content was measured with a Turner 112 fluorometer after aceton extraction (Strikland and Parsons, 1972). Phytoplankton samples (volume $500 \mathrm{ml}$ ) were filtered through a plankton net (mesh diameter $10 \mu \mathrm{m}$ ) and separated into two size categories: microphytoplankton $(>10 \mu \mathrm{m})$ and nano-/pico-fraction $(<10 \mu \mathrm{m})$.

Bacteria and HNF were enumerated by epifluorescence microscopy ("Olympus" BX50 at a magnification of X1000) using the standard acridine orange direct counting technique (Hobbie et al., 1977) for bacteria, and proflavine staining technique for HNF (Haas, 1982). Sample volumes of $2 \mathrm{ml}$ for bacteria and $10 \mathrm{ml}$ for HNF were filtered through a black isopore membrane filter (pore size $0.2 \mu \mathrm{m}$ ). For biovol- ume estimates, length and width of bacterial and HNF cells were measured with an eyepiece graticule (New Portion G12, Graticules, Ltd, UK). Biovolume was then converted to carbon biomass, assuming 0.220 pgC $\mu \mathrm{m}^{-3}$ for bacteria (Bratbak and Dundas, 1984) and HNF (Borsheim and Bratbak, 1987).

Bacterial cell production was measured from DNA synthesis based on incorporation rates of ${ }^{3} \mathrm{H}$ thymidine (Fuhrman and Azam, 1982). (Methyl- ${ }^{3} \mathrm{H}-$-) thymidine was added to $10 \mathrm{ml}$ samples at a final concentration of $10 \mathrm{nmol}$ (specific activity $86 \mathrm{Ci}$ $\left.\mathrm{mmol}^{-1}\right)$. Triplicate samples and a formaldehyde killed adsorption control (final concentration $0.5 \%$ ) were incubated for 1 hour. The incubations were stopped with formaldehyde (final concentration $0.5 \%$ ). The thymidine samples were extracted with ice-cold TCA according to Fuhrman and Azam (1982). The TCA-insoluble fraction was collected by filtering the sample through a $0.2 \mu \mathrm{m}$ pore size Sartorius filter. The percentage of thymidine converted to protein was not checked. Conversion factors for bacterial cell production were calculated from bacterial cell number and ${ }^{3} \mathrm{H}$-tymidine incorporation during bacterial growth in $1 \mu \mathrm{m}$-prefiltered seawater (Riemann et al., 1987): $\mathrm{CF}=\left(\mathrm{N}_{2}-\mathrm{N}_{1}\right) /{ }^{3} \mathrm{H}$, where $\mathrm{N}_{1}$ is the number of bacteria in the beginning of the experiment, $\mathrm{N}_{2}$ is the number of bacteria at the end of the experiment, ${ }^{3} \mathrm{H}$ integrated ${ }^{3} \mathrm{H}$-thymidine incorporation rate during the experiment.

The temperature was measured with reversed thermometers in 1998, while salinity was determined using an inductive salinometer (model RS10). The vertical temperature and conductivity profiles during 1999 were measured with a CTD multiparameter probe.

\section{Statistical analysis}

Statistical analysis was performed using standard methods such as Pearson's correlations and Multiple regression analysis. Principal component analysis (PCA) was used to extract the main patterns of seasonal changes in biomass. The data input to each analysis consisted of a set of variables representing seasonal fluctuations of biomass. The analyses were all based on correlation matrices involving each variable being standardised to zero mean and unit variance. The purpose of this was to eliminate differences in biomass between the groups studied, leaving only the relative month-to-month changes in biomass. The Varimax rotation of extracted PC com- 


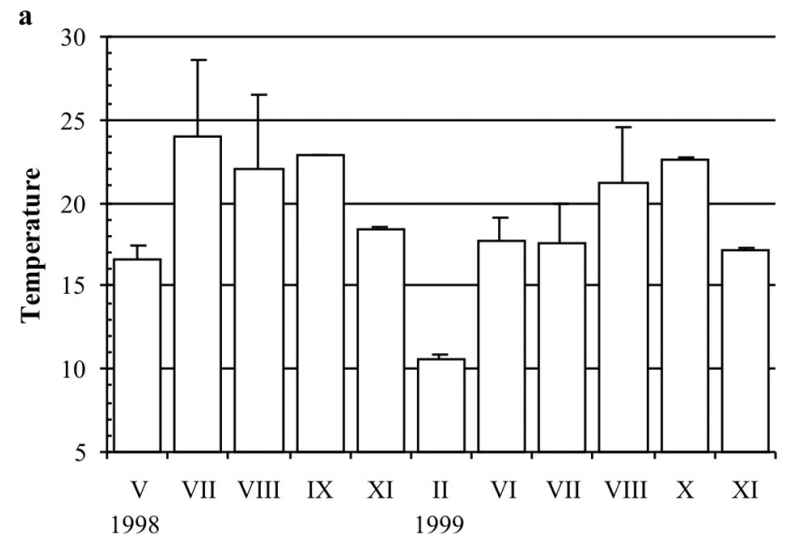

b

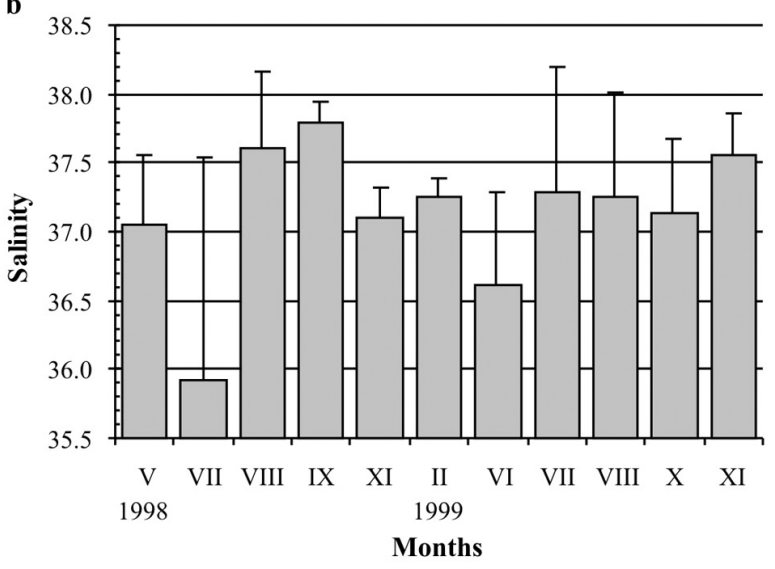

FIG. 2. - Seasonal variations of average temperature (a) and salinity (b) in the eastern part of Kaštela Bay; error bars represent standard deviations.

ponents was used in order to obtain a better insight into the behaviour of observation variables. All statistical analyses were performed using the statistical package StatSoft Inc. (2000) STATISTICA for Windows version 5.5. (http://www.statsoft.com).

\section{RESULTS}

\section{Hydrographical parameters}

The water column was generally isothermal in winter and the lowest average temperature value was $10.60 \pm 0.24^{\circ} \mathrm{C}$ in February 1999 (Fig. 2a). The thermal stratification began as early as April, and by early summer the thermocline was formed. The maximal temperature $\left(27.16^{\circ} \mathrm{C}\right)$ and the highest vertical range between recorded maximum and minimum $\left(10.69^{\circ} \mathrm{C}\right)$ occurred in August 1998. In September, the vertical stratification disappeared and the entire water column had a temperature of $\sim 23^{\circ} \mathrm{C}$. The rest of the year was characterised by a temperature decrease and there were no significant differences in temperature between the layers.

Average water column salinity values ranged between $35.92 \pm 1.62$ (July 1998) and $37.79 \pm 1.15$ (September 1998) (Fig. 2b). A minimum of 33.81 and maximum of 38.18 were observed in summer 1998, in the surface layer in July and in the bottom layer in August respectively. The highest salinity range (3.91) was also found during the summer. During the autumn-winter period all layers had an almost uniform salinity of $\sim 37.50$ while the halocline started to develop with the beginning of the spring heating. Salinity values increased with depth, while the seasonal changes of this parameter declined with depth.

\section{Biotic parameters}

\section{Phytoplankton}

There was a regular seasonal distribution in chlorophyll $a$ concentration during the study period (Fig. 3). High concentrations were recorded during the warm period of the year, with a maximal water column average value of $9.16 \pm 4.97 \mu \mathrm{g} \mathrm{l}^{-1}$ in July 1998 , and a real value of $15.65 \mu \mathrm{g} \mathrm{l}^{-1}$ at the surface. However, chlorophyll $a$ concentrations during the rest of the year were considerably lower and oscillated from $0.70 \pm 0.23$ (November 1998) to $2.84 \pm$ $0.67 \mu \mathrm{g} \mathrm{l}^{-1}$ (April 1999).

Fluctuations of phytoplankton biomass were almost equally affected by changes of both phytoplankton fractions. Exceptions were recorded in July 1998, when smaller phytoplankton prevailed, and

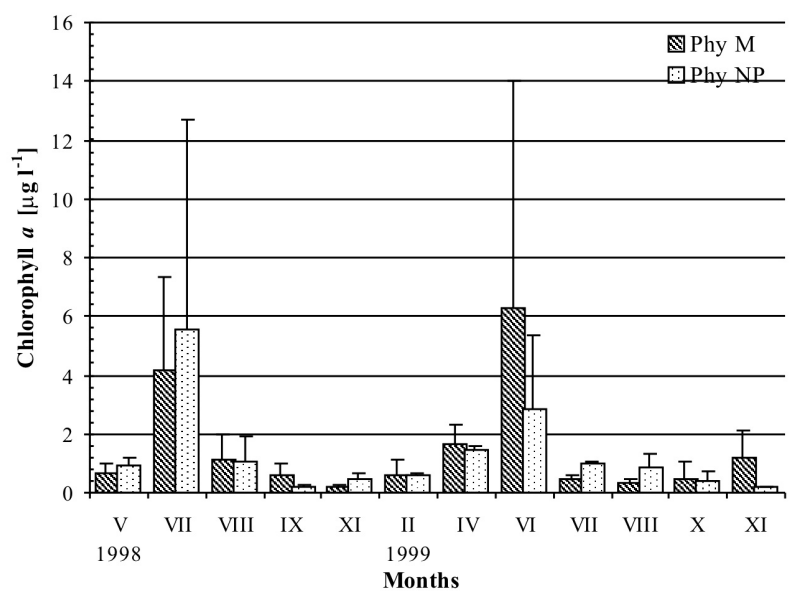

FIG. 3. - Seasonal changes of average chlorophyll $a$ concentration in the eastern part of Kaštela Bay; error bars represent standard deviations (Phy NP, nano- and picophytoplankton; Phy M, micro phytoplankton). 


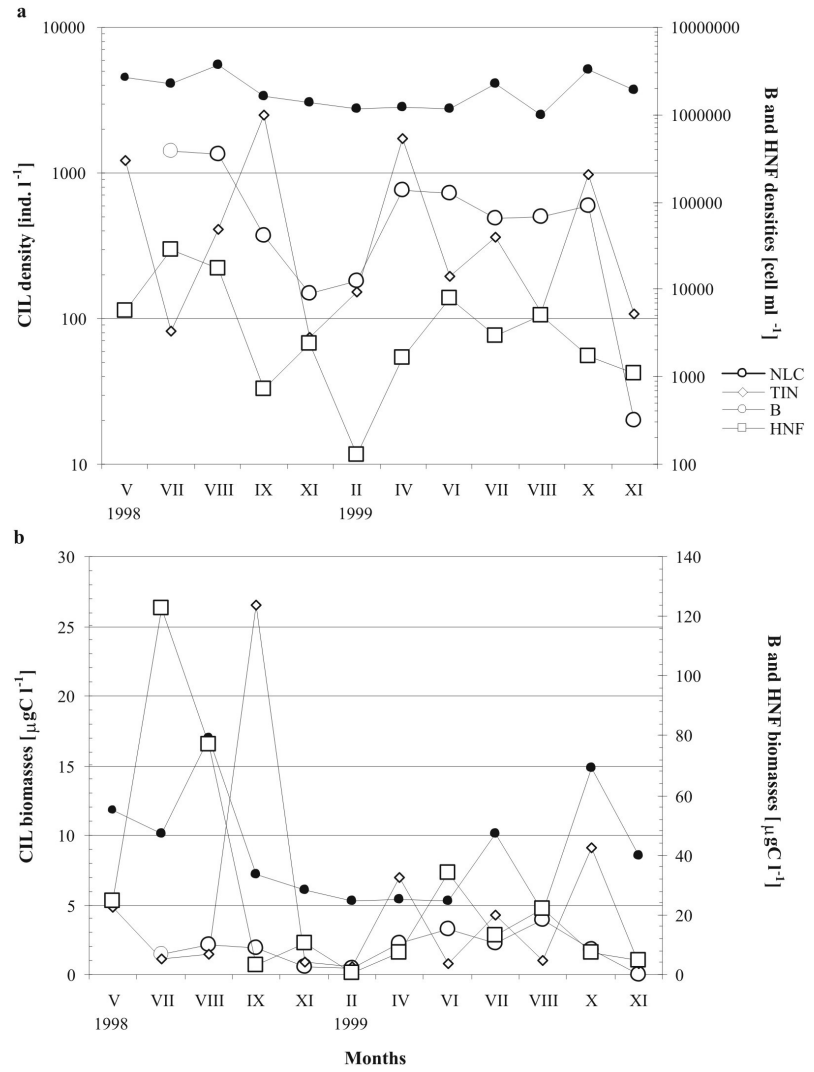

FIG. 4. - Temporal variability in average values of abundance (a) and biomass (b) of bacteria, HNF and ciliated protozoa (CIL, ciliated protozoa; NLC, nonloricate ciliates; TIN, tintinnids; B, bacteria; $\mathrm{HNF}$, heterotrophic nanoflagellates).

June 1999 when microphytoplankton dominated (Fig. 3). The highest chlorophyll $a$ concentration of microphytoplankton $\left(11.73 \mu \mathrm{g} \mathrm{l}^{-1}\right)$ was recorded in June 1999 at the surface. A similar value for the smaller phytoplankton fraction $\left(13.78 \mu \mathrm{g} \mathrm{Chl} a \mathrm{l}^{-1}\right)$ was found in July 1998, also at the surface.

\section{Bacterioplankton}

Temporal variability of bacterioplankton was characterised by a summer-autumn peak in both density and biomass, with the highest mean water column values of $3.78 \pm 1.48 \times 10^{6}$ cells ml $\mathrm{ml}^{-1}$ and $78.93 \pm 30.94 \mu \mathrm{gC}^{-1}$ respectively recorded in August 1998 (Fig. 4). The lowest values for both parameters were found in August 1999, when 1.01 $\pm 0.31 \times 10^{6}$ cells $\mathrm{ml}^{-1}$ and $21.04 \pm 6.39 \mu \mathrm{gC} \mathrm{l}^{-1}$ were recorded. During the whole study period bacteria were the most abundant in the surface layer and the greatest vertical range between maximum and minimum values of density and biomass was observed during the thermal stratification of the water column.

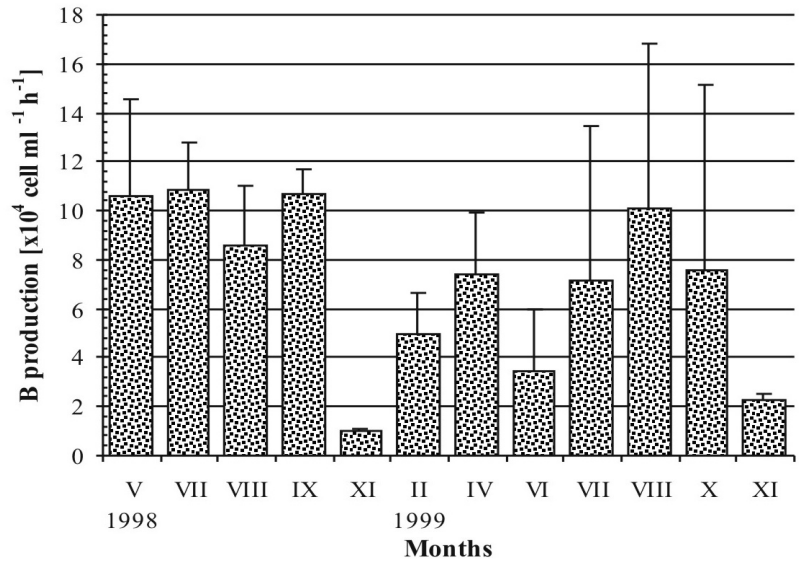

FIG. 5. - Seasonal changes in bacterial production in the eastern part of Kaštela Bay; error bars represent standard deviations.

Bacterial production varied from $0.98 \times 10^{4}$ to $16.16 \times 10^{4}$ cell ml$^{-1} \mathrm{~h}^{-1}$ (mean value $7.05 \pm 4.64 \times$ $10^{4}$ cell $\mathrm{ml}^{-1} \mathrm{~h}^{-1}$ ), with the maximum recorded in the surface layer in October 1999 (Fig. 5). The largest seasonal variation was recorded at the surface, while bacterial production in the bottom layer showed few temporal fluctuations. The exception was observed in November 1998, when bacterial production in the whole water column was uniform and had the lowest value of approximately $10^{4} \mathrm{cell} \mathrm{ml}^{-1} \mathrm{~h}^{-1}$.

\section{Heterotrophic nanoflagellates (HNF)}

Fluctuations in abundance and biomass of heterotrophic nanoflagellates (HNF) showed a characteristic seasonal pattern (Fig. 4). The highest values were observed in the summer months, while the decrease in number and biomass began as early as September. During the whole autumn-winter period both values remained low. The maximal water column average density of $28 \pm 19 \times 10^{3}$ cells $\mathrm{ml}^{-1}$ and biomass of $123 \pm 82 \mu \mathrm{gC} \mathrm{l}^{-1}$ were found in July 1998. In the same month, $40 \times 10^{3}$ HNF cells per millilitre of seawater were found at the surface, while the biomass was $177 \mu \mathrm{gC} \mathrm{l}^{-1}$. The increase in both parameters during the summer of 1999 was of lower intensity.

\section{Ciliated protozoa}

Temporal variability in ciliated protozoa density was characterised by peaks in spring and autumn, with average water column values higher than 2500 ind. $1^{-1}$. In addition, a relatively high ciliate number was observed in the summer of 1998. This seasonal 
distribution was mostly due to the fluctuation of loricates (TIN) $\left(r^{2}=0.65, P<0.0001\right)$, while nonloricates (NLC) quantitatively dominated during the summer (Fig. 4a). The highest average abundance of NLC $\left(1430 \pm 1348\right.$ ind. $\left.^{-1}\right)$ was found in July 1998 and was followed by a marked decrease in the autumnwinter period. Oscillations in 1999, especially from April to October, were insignificant.

In the NLC size category, during the spring peak, the dominating organisms were those with biovolume of $10^{3}-10^{4} \mu \mathrm{m}^{3}$ and cell length (CL) 20-40 $\mu \mathrm{m}$ (NLC II). They represented between 72 and $85 \%$ of the total NLC number. During 1999 the contribution of this fraction to the total ciliate density decreased and was equal to the contribution of NLC III $\left(10^{4}\right.$ $10^{5} \mu \mathrm{m}^{3}$, CL $\left.40-80 \mu \mathrm{m}\right)$. Tintinnids prevailed in the samples collected during the spring and autumn (Fig. 4a). The pronounced peak of $2477 \pm 2847$ ind. $\mathrm{l}^{-1}$ was observed in September 1998 when neritic water species Codonellopsis schabi predominated. The spring maximum was of lower intensity (1744 \pm 2514 ind. $^{-1}$ ) and the most numerous species was Helicostomella subulata.

a
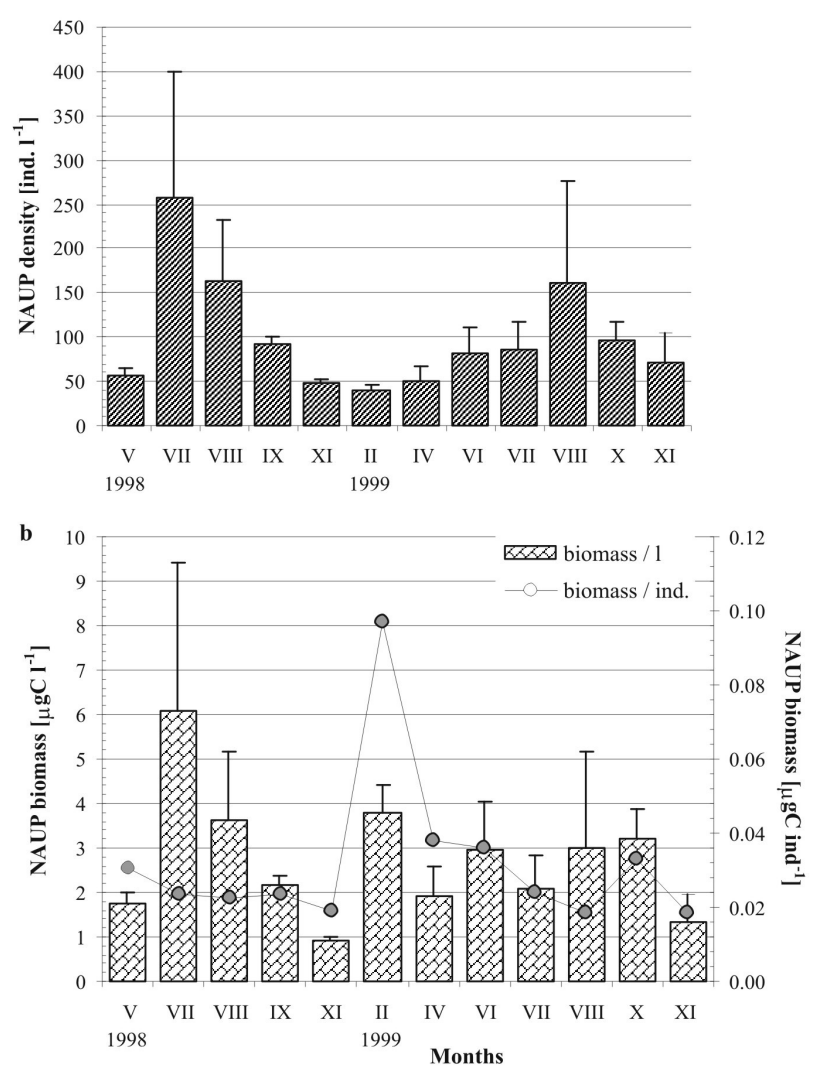

FIG. 6. - Seasonal variability in copepod nauplii average density (a) and biomass (b) in the eastern part of Kaštela Bay; error bars represent standard deviations.
Monthly fluctuations in biomass of both ciliate groups are shown in Figure 4b. The average column values oscillated from $0.78 \pm 0.32$ to $28.44 \pm 12.44$ $\mu \mathrm{gC} \mathrm{1}^{-1}$. These values were recorded in November 1999 and September 1998 respectively. These fluctuations were mostly affected by seasonal oscillations of TIN biomass $\left(\mathrm{r}^{2}=0.94, \mathrm{p}<0.0001\right)$ with the pronounced maximum of $39.46 \mu \mathrm{gC} \mathrm{l}^{-1}$ observed in September 1998 at $10 \mathrm{~m}$ depth. TIN biomass values during the 1999 were approximately three times less than those recorded in 1998. Nevertheless, seasonal oscillations of NLC biomass could explain only $10 \%$ of the total ciliate biomass. The highest biomass value for this NLC group of organisms of $11.34 \mu \mathrm{gC}^{-1}$ was found in August 1999 at the surface (average $3.92 \pm 5.09 \mu \mathrm{gC}^{-1}$ ). NLC biomass distribution depended on partition of NLC with a biovolume higher than $10^{4} \mu \mathrm{m}^{3}$ and $\mathrm{CL}>40 \mu \mathrm{m}$, i.e. NLC III and NLC IV. The Pearson's correlation coefficients between total ciliate biomass and the biomass of these two groups were 0.91 and 0.80 respectively.

NLC and TIN compositions, as well as temporal and vertical fluctuations in density and biomass, have been presented in detail previously (Bojanić et al., 2005).

\section{Copepod nauplii}

An obvious seasonal trend was present in the records of copepod nauplii that were highest during the summer (Fig. 6a). The peak of naupliar popula-

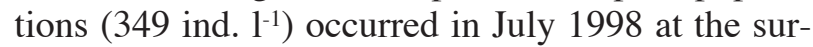
face, with the water column average of $258 \pm 141$ ind. $1^{-1}$. The lowest abundance of copepod nauplii was found during the colder part of the year, with the minimum column average $\left(39 \pm 7\right.$ ind. $\left.1^{-1}\right)$ recorded in February 1999.

The biomass of copepod nauplii varied considerably depending on the sampling period (Fig. 6b). During 1998, biomass fluctuation was significantly correlated with naupliar abundance $\left(\mathrm{r}^{2}=0.98\right.$, $\mathrm{p}<0.0001)$. The highest value of $8.23 \mu \mathrm{gC}^{-1}$ was found at the sea surface in July 1998. However, in 1999 the connection between these parameters was less pronounced $\left(\mathrm{r}^{2}=0.36, \mathrm{p}<0.001\right)$. The changes observed in the relationship between biomass and abundance of copepod nauplii can be attributed to the prevalence of large sized nauplii with an average biomass of $0.097 \mu \mathrm{gC}$ per organism in February 1999 , and to the occurrence of quite uniform bio- 
mass values $\left(\sim 3 \mu \mathrm{gC} \mathrm{l}^{-1}\right)$ from June to October 1999, when the mean biomass of organisms varied from 0.019 to $0.036 \mu \mathrm{gC}$ (Fig. 6b).

\section{Interrelationships between parameters}

\section{Pearson's correlations}

The Pearson's correlations illustrated a relationship between all the above-mentioned biotic parameters with the abiotic parameters temperature and salinity (Table 1). A high correlation coefficient indicates a similar annual cycle of the studied parameters. The highest correlation coefficients with temperature were recorded for bacterial production ( $\mathrm{r}=0.64)$, HNF biomass $(\mathrm{r}=0.62)$ and NLC II biomass $(\mathrm{r}=0.60)$. Salinity had a significant negative correlation with chlorophyll $a$ concentration of nano- and pico-phytoplankton (Phy NP) $(\mathrm{r}=-0.89)$ and copepod nauplii biomass $(\mathrm{r}=-0.81)$. Somewhat lower significant correlations were found between salinity and biomasses of NLC II and NLC III.

Based on the analysis of the relationships between the biological components studied included in the microbial food web, significant values were recorded between Phy NP and biomasses of HNF, NLC II and copepod nauplii. HNF was correlated with bacterial production, as well as with the biomass of NLC I and NLC II. The NLC III biomass had a significant correlation with chlorophyll $a$ concentration of microphytoplankton (Phy M) and NLC IV biomass. Besides Phy NP, copepod nauplii biomass had a significant correlation with bacterial production and biomasses of HNF and NLC II. The numerical values of all coefficients are shown in Table 2.
TABLE 1 - Pearson's correlation coefficients between biomass values of bacteria, heterotrophic nanoflagellates, ciliates, copepod nauplii, concentration of phytoplankton chlorophyll $a$ and bacterial production and temperature and salinity (Significant correlation coefficients are printed in bold; $\mathrm{N}=18, \mathrm{P}<0.05)$.

\begin{tabular}{lcc}
\hline & \multicolumn{2}{c}{ ABIOTIC PARAMETERS } \\
& Temperature & Salinity \\
\hline Phy M & 0.08 & -0.41 \\
Phy NP & 0.42 & $\mathbf{- 0 . 8 9}$ \\
B & $\mathbf{0 . 5 0}$ & -0.28 \\
BP & $\mathbf{0 . 6 4}$ & -0.46 \\
HNF & $\mathbf{0 . 6 2}$ & $\mathbf{- 0 . 7 3}$ \\
NLC I & 0.45 & -0.12 \\
NLC II & $\mathbf{0 . 6 0}$ & $\mathbf{- 0 . 7 8}$ \\
NLC III & 0.29 & $\mathbf{- 0 . 5 1}$ \\
NLC IV & 0.29 & -0.07 \\
TIN & 0.31 & 0.24 \\
NAUP & $\mathbf{0 . 5 3}$ & $\mathbf{- 0 . 8 1}$ \\
& & \\
\hline
\end{tabular}

Phy M, micro-phytoplankton; Phy NP, nano- and pico-phytoplankton; B, bacteria; BP, bacterial production; HNF, heterotrophic nanoflagellates; NLC, nonloricate ciliates: I - Volume $<10^{3}$ $\mu \mathrm{m}^{3}$, Cell Length $<20 \mu \mathrm{m}$; II $-\mathrm{V} 10^{3}-10^{4} \mu \mathrm{m}^{3}$, CL 20-40 $\mu \mathrm{m}$; III $\mathrm{V} 10^{4}-10^{5} \mu \mathrm{m}^{3}$, CL $40-80 \mu \mathrm{m}$; IV $-\mathrm{V}>10^{5} \mu \mathrm{m}^{3}, \mathrm{CL}>80 \mu \mathrm{m}$;

TIN, tintinnids; NAUP, copepod nauplii.

\section{Principal component analysis}

Plankton groups included in the Principal component analysis (PCA) were phytoplankton, bacterioplankton, HNF, ciliated protozoa and copepod nauplii. The PCA extracted five clusters enclosing plankton groups with similar patterns of seasonal variability (Fig. 7). The first cluster comprised the smaller phytoplankton fraction, HNF, NLC II and copepod nauplii. The second consisted of the NLC III and IV size categories, while the third cluster contained only the microphytoplankton fraction. Bacterioplankton and NLC I were included in the fourth group and TIN made the fifth cluster.

TABLE 2. - Pearson's correlation coefficients between the biomass values of bacteria, heterotrophic nanoflagellates, nonloricate ciliates, copepod nauplii and concentration of phytoplankton chlorophyll $a$ and bacterial production (Significant correlation coefficients are printed in bold; $\mathrm{N}=20, \mathrm{P}<0.05$ ).

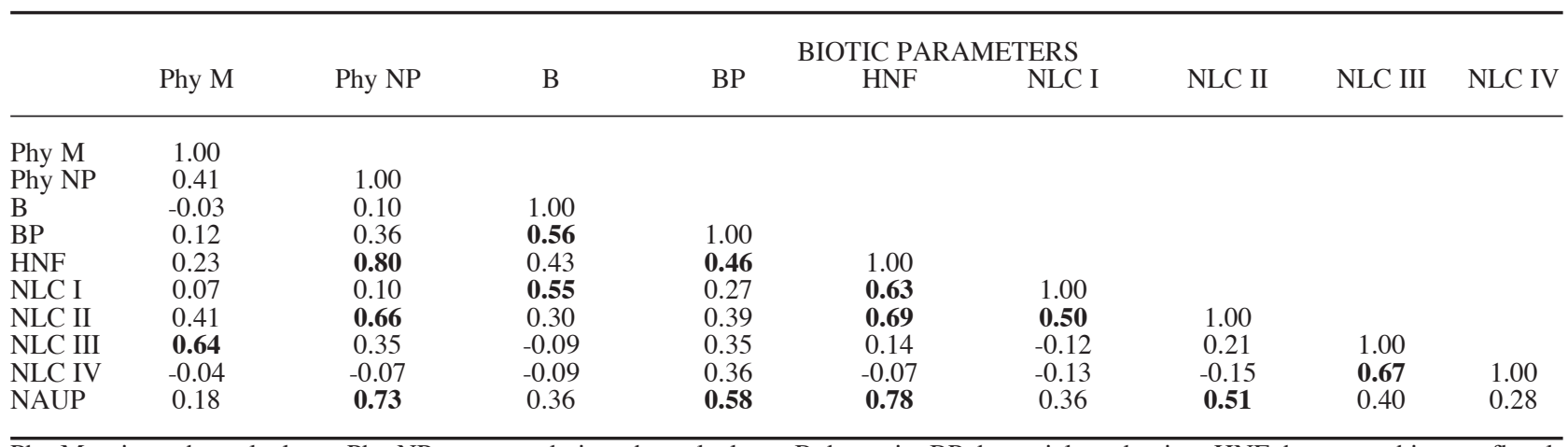

Phy M, micro-phytoplankton; Phy NP, nano- and pico-phytoplankton; B, bacteria; BP, bacterial production; HNF, heterotrophic nanoflagel-

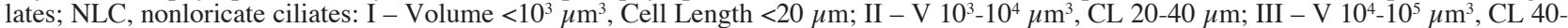
$80 \mu \mathrm{m}$; IV $-\mathrm{V}>10^{5} \mu \mathrm{m}^{3}$, CL $>80 \mu \mathrm{m}$; NAUP, copepod nauplii. 


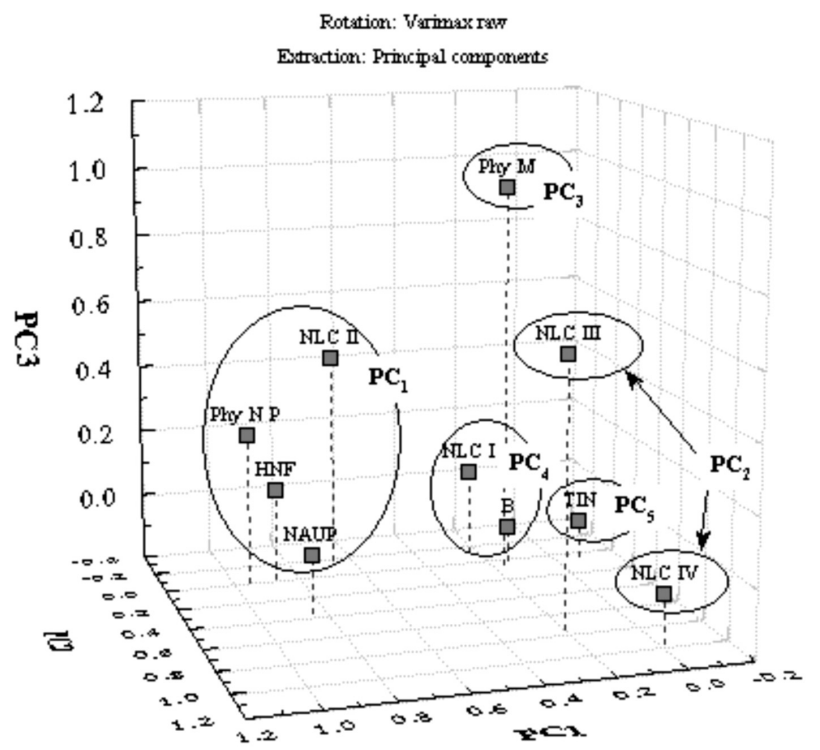

FIG. 7. - Ordering of biomasses of phytoplankton, bacteria, HNF, ciliated protozoa and copepod nauplii obtained by Principal component analysis. (Phy NP, nano- and pico-phytoplankton; Phy M, micro-phytoplankton; $\mathrm{B}$, bacteria; HNF, heterotrophic nanoflagellates; NLC, nonloricate ciliates: I - Volume $<10^{3} \mu \mathrm{m}^{3}$, Cell Length $<20 \mu \mathrm{m}$; II $-\mathrm{V} 10^{3}-10^{4} \mu \mathrm{m}^{3}$, CL $20-40 \mu \mathrm{m}$; III $-\mathrm{V} 10^{4}-10^{5} \mu \mathrm{m}^{3}$, CL 40-80 $\mu \mathrm{m}$; IV - V >10 $\mu \mathrm{m}^{3}$, CL $>80 \mu \mathrm{m}$; TIN, tintinnids; NAUP, copepod nauplii).

\section{Multiple regression analysis}

Seasonal fluctuations of HNF biomass were positively correlated with Phy NP, bacterial biomass and temperature, and negatively correlated with salinity. HNF biomass showed the strongest correlation ( $\mathrm{r}=0.80, \mathrm{P}<0.001)$ with Phy NP whose fluctuations explain $64 \%$ of the variability in HNF biomass. This relationship was improved by including bacteria as an additional independent variable. The coefficient of multiple regression (R), which measures the overall degree of association between HNF and independent variables was 0.87 , which means that about $76 \%$ of the variability in HNF biomass can be explained with Phy NP and bacteria. The relative importance of bacterial and Phy NP biomass in controlling HNF biomass is shown by the beta coefficients $(\beta)$, which represent regression coefficients stated in terms of their standard deviations. Each increase of one standard deviation (SD) in the value of Phy NP chlorophyll $a$ concentration will be accompanied (if bacterial biomass stays constant) by an increase of about $0.77 \mathrm{SD}$ in the value of HNF biomass. On the other hand, each increase of one SD in the value of bacterial biomass will be accompanied by a rather smaller increase in the value of HNF biomass (about $0.34 \mathrm{SD}$ ). Although a high correlation between HNF and in situ temperature was established $(\mathrm{r}=0.62, \mathrm{P}<0.001)$, including temperature as an additional independent variable slightly improved the multiple regression model $\left(\mathrm{R}^{2}=0.78\right)$. The simultaneous effect of different variables on biomasses of HNF and two size categories of NLC are presented in Table 3.

TABLE 3. - Simultaneous effect of different variables on biomasses of heterotrophic nanoflagellates and two size categories of nonloricate ciliates.

\begin{tabular}{|c|c|c|c|c|c|c|}
\hline Dependent variable & Independent variables & $\mathrm{r}$ & $r_{p}$ & $\beta$ & $\mathrm{R}$ & $\mathrm{R}^{2}$ \\
\hline HNF & $\begin{array}{l}\text { Bacteria } \\
\text { Phy NP }\end{array}$ & $\begin{array}{l}0.43 \\
0.80 * * *\end{array}$ & $\begin{array}{l}0.57 * * \\
0.84 * * *\end{array}$ & $\begin{array}{l}0.34 \\
0.77\end{array}$ & $0.87 * * *$ & 0.76 \\
\hline HNF & $\begin{array}{l}\text { Bacteria } \\
\text { Phy NP } \\
\text { Temperature }\end{array}$ & $\begin{array}{l}0.43 \\
0.80^{* * * *} \\
0.62^{* *}\end{array}$ & $\begin{array}{l}0.40 \\
0.81 * * * \\
0.31\end{array}$ & $\begin{array}{l}0.24 \\
0.71 \\
0.19\end{array}$ & $0.89 * * *$ & 0.78 \\
\hline NLC I & $\begin{array}{l}\text { Bacteria } \\
\text { HNF }\end{array}$ & $\begin{array}{l}0.48 * * \\
0.48 * *\end{array}$ & $\begin{array}{l}0.36 \\
0.36^{*}\end{array}$ & $\begin{array}{l}0.34 \\
0.35\end{array}$ & $0.57 * *$ & 0.33 \\
\hline NLC I & $\begin{array}{l}\text { Bacteria } \\
\text { HNF } \\
\text { Phy NP }\end{array}$ & $\begin{array}{l}0.48^{* *} \\
0.48^{* *} \\
0.12\end{array}$ & $\begin{array}{l}0.04 \\
0.87 * * * \\
-0.81 * * *\end{array}$ & $\begin{array}{l}0.02 \\
1.49 \\
-1.09\end{array}$ & $0.91 * * *$ & 0.83 \\
\hline NLC II & $\begin{array}{l}\text { HNF } \\
\text { Temperature }\end{array}$ & $\begin{array}{l}0.76 \text { *** } \\
0.53 * * *\end{array}$ & $\begin{array}{l}0.84 * * * \\
0.14\end{array}$ & $\begin{array}{l}0.85 \\
0.08\end{array}$ & $0.90 * * *$ & 0.81 \\
\hline NLC II & $\begin{array}{l}\text { HNF } \\
\text { Phy NP } \\
\text { Temperature }\end{array}$ & $\begin{array}{l}0.76^{* * *} \\
0.65 * * * \\
0.53 * * *\end{array}$ & $\begin{array}{l}0.69 * * \\
0.25 \\
0.21\end{array}$ & $\begin{array}{l}0.72 \\
0.17 \\
0.11\end{array}$ & $0.92 * * *$ & 0.85 \\
\hline
\end{tabular}

*, $\mathrm{P}<0.05 ; * *, \mathrm{P}<0.01 ; * * *, \mathrm{P}<0.001$; HNF, heterotrophic nanoflagellates; Phy NP, nano- and pico-phytoplankton; NLC, nonloricate ciliates: I - Volume $<10^{3} \mu \mathrm{m}^{3}$, Cell Length $<20 \mu \mathrm{m}$; II - V $10^{3}-10^{4} \mu \mathrm{m}^{3}$, CL $20-40 \mu \mathrm{m}$; r, correlation coefficient; $\mathrm{r}_{\mathrm{p}}$, partial correlation coefficient; $\beta$ (beta coefficient), regression coefficients (b) stated in terms of their standard deviations; $R$, multiple regression coefficient; $R^{2}$, multiple determination coefficient. 
Seasonal fluctuations of NLC I were positively correlated with bacteria $(\mathrm{r}=0.48, \mathrm{P}<0.01)$ and $\mathrm{HNF}$ $(\mathrm{r}=0.48, \mathrm{P}<0.01)$. The regression model that includes both bacteria and HNF biomasses as independent variables explains about $33 \%$ of the variability in NLC I biomass. Although the correlation between NLC I and Phy NP was very low ( $\mathrm{r}=0.12)$, including Phy NP as an additional independent variable considerably improved the multiple regression model, which now explained $83 \%$ of the variability in NLC I biomass. Seasonal fluctuations of NLC II correlated strongly with HNF, which explained about $58 \%$ of the variability in the NLC II biomass. Including temperature as an additional independent variable significantly improved the multiple regression model $\left(\mathrm{R}^{2}=0.81\right)$. However, including Phy NP as an additional independent variable in this case only slightly improved the multiple regression model $\left(\mathrm{R}^{2}=0.85\right)$. Regression between NLC III biomass and Phy $\mathrm{M}$ as an independent variable $\left(\mathrm{r}^{2}=0.23\right)$ was significantly improved by including $\mathrm{HNF}$ and salinity as additional independent variables $\left(\mathrm{R}^{2}=0.57\right)$. Similarly, the regression between NLC IV and NLC III as an independent variable $\left(\mathrm{r}^{2}=0.22\right)$ was significantly improved by including Phy $\mathrm{M}$ and $\mathrm{HNF}$ as additional independent variables $\left(\mathrm{R}^{2}=0.84\right)$.

\section{DISCUSSION}

\section{Plankton food web structure}

A phytoplankton bloom occurring in the eutrophicated part of Kaštela Bay during summer has been reported previously (Marasović and Vukadin, 1982). The phytoplankton bloom was dominated by dinoflagellate Gonyaulax polyedra. Since 1980, when it was recorded for the first time, it has become a regular occurrence in this part of the bay and this dinoflagellate constitutes over $93 \%$ of the phytoplankton density during the bloom $\left(1.8 \times 10^{7}\right.$ cell $~^{-1}$ ) (Marasović and Vukadin, 1982; Marasović and Pucher-Petković, 1991). However, the onset of the summer bloom during our study in July 1998 was the result of a rapid increase in the nano- and picophytoplankton fraction (Phy NP), especially the green algae of the genus Chlorella. The observed exception was probably influenced by a haste decrease in salinity compared to the salinity value recorded that May (Fig. 2). Maximal abundance of
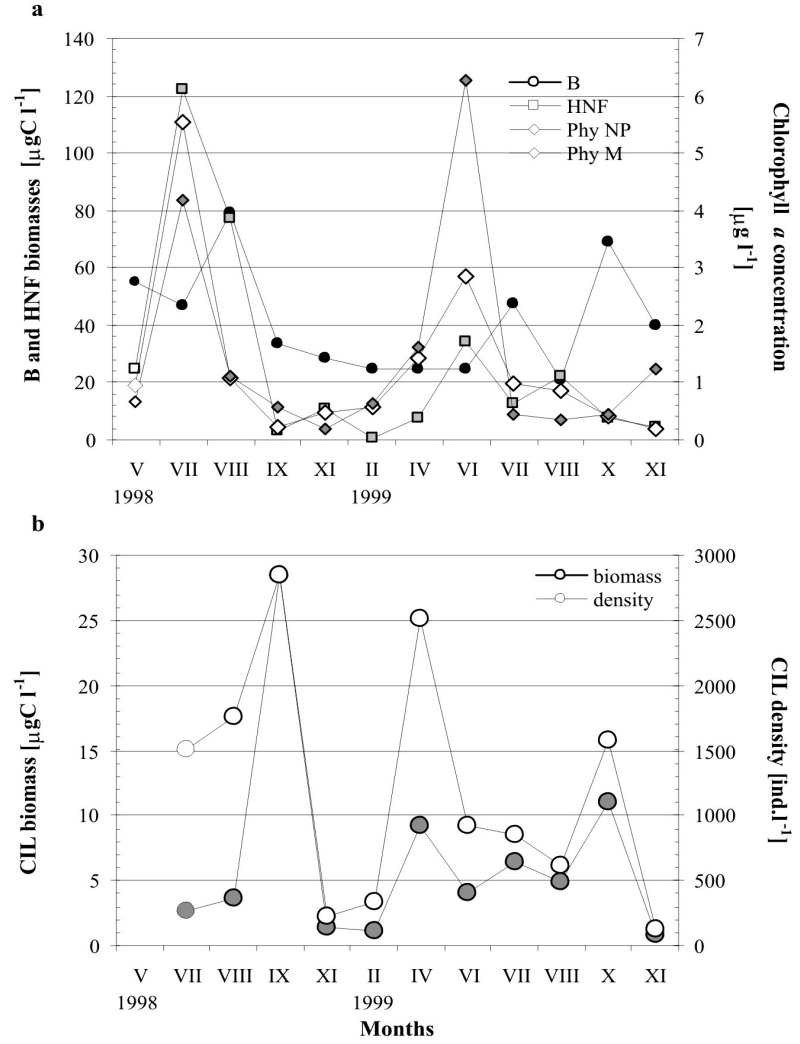

FIG. 8. - Seasonal variability in average values of biomasses of bacterioplankton, HNF, ciliates and chlorophyll $a$ concentration (B, bacterioplankton; HNF, heterotrophic nanoflagellates; Phy NP, nano- and pico-phytoplankton fraction; Phy M, microphytoplankton; CIL, ciliated protozoa).

bacterioplankton and HNF were also always recorded in summer (Fig. 8a). These life conditions were also suitable for the growth of the ciliate component of microzooplankton (Fig. 8b). Significant correlations between these biotic parameters suggest strong relationships in the microbial food web (Table 2). Earlier studies on the relationship between bacteria, phytoplankton and HNF in the eutrophicated part of Kaštela Bay showed that as much as $64 \%$ of variation in bacterial abundance could be explained either by variability in abundance of HNF or by predatorprey dependence (Krstulović et al., 1997). However, our data showed a slightly weaker link between bacteria and HNF abundance $(\mathrm{r}=0.40, \mathrm{~N}=36, \mathrm{P}<0.05)$ and suggested that organisms other than HNF could be important predators of bacteria and/or that other loss processes could be more important than predation. Gasol and Vaque (1993) tried to justify the weak link between bacteria and HNF with the explanation that predation on HNF could result in variations of the predator-prey relation between HNF and bacteria (trophic cascade effect). In our study, Multiple regression analysis indicated that bacterial 
and Phy NP biomasses were highly temperature dependent and therefore temperature influenced variation in HNF biomass indirectly through the changes in bacterial and Phy NP biomass. This conclusion is supported by the much lower partial correlation $\left(r_{p}=0.31\right)$ between HNF and in situ temperature (correlation between $\mathrm{HNF}$ and temperature when the effect of Phy NP abundance was removed). Consequently, our results indicate that biomasses of phytoplankton and bacterioplankton were primarily influenced by abiotic parameters.

Comparative studies generally confirm the importance of resource regulation of bacteria (Ducklow, 1992; Sanders et al., 1992; Gasol and Vaqué, 1993). Fuks (1995) found that in the northern Adriatic Sea $45 \%$ of the bacterial biomass variability could be explained by the bottom-up model and only $20 \%$ by the top-down model. However, earlier research in Kaštela Bay demonstrated the strong HNF grazing pressure on bacteria during most of the year, particularly during the warmer months (Šolić and Krstulović, 1994; Šolić et al., 1998).

Principal component analysis extracted bacterioplankton and NLC I as the same cluster and pointed out the significant relationship between these groups. Besides bacteria, NLC I biomass had a significant correlation with HNF. Including Phy NP as an independent variable additionally improved the multiple regression model. The coefficients of partial correlation explained the real nature of this relationship with a high positive relationship of NLC I with HNF ( $\left.\mathrm{r}_{\mathrm{p}}=0.87\right)$, and negative correlation with Phy NP $\left(r_{p}=-0.81\right)$, which suggests a strong trophic cascade effect (Table 3). Namely, the smallest NLC size category controlled the biomass of bacterioplankton indirectly by grazing on HNF populations. NLC II biomass also correlated strongly with HNF biomass. Including temperature and Phy NP as independent variables in the statistical analysis showed that HNF were more important as a prey for NLC II than Phy NP, as well as the indirect influence of temperature through the fluctuation of HNF biomass. Very high average density values of NLC II populations in summer 1998 suggested that NLC II could act as an important factor of top-down control of HNF. Therefore, our results confirmed the hypothesis of the indirect control exerted by microzooplankton on bacterial biomass through HNF removal (Dolan and Gallegos, 1991; Weisse, 1991; Thingstad and Rassoulzadegan, 1995; Fonda Umani and Beran, 2003). The above mentioned authors

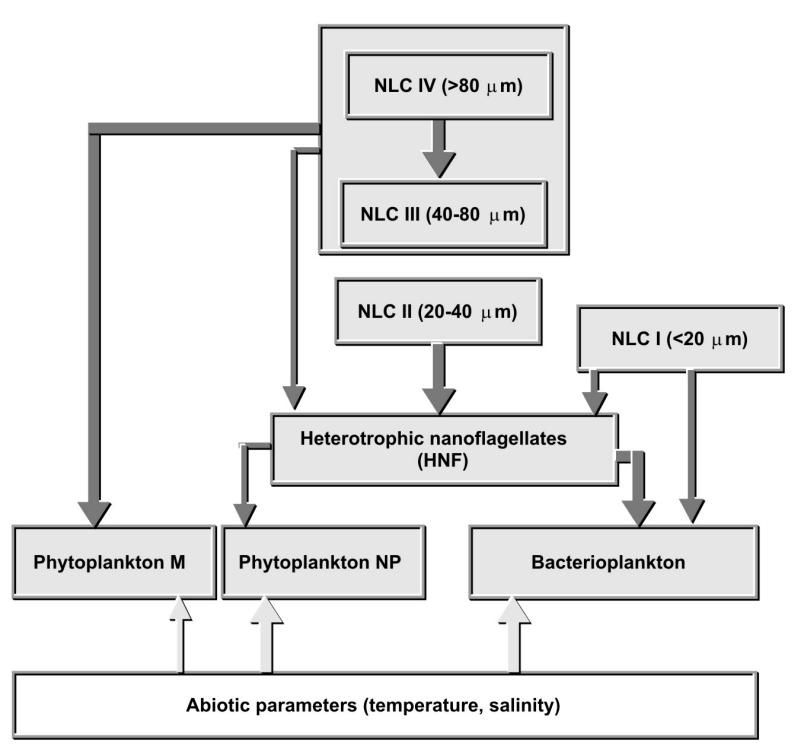

FIG. 9. - Schematic review of direct relationships between the abiotic and some biotic parameters within the microbial food web in the eastern part of the Kaštela Bay obtained using Pearson's correlations, Multiple regression analysis and Principal component analysis (Phy NP, nano- and pico-phytoplankton fraction; Phy M, microphytoplankton fraction; NLC, nonloricate ciliates, $\mathrm{I}<10^{3} \mu \mathrm{m}^{3}$, $\left.\mathrm{II}=10^{3}-10^{4} \mu \mathrm{m}^{3}, \mathrm{III}=10^{4}-10^{5} \mu \mathrm{m}^{3}, \mathrm{IV}>10^{5} \mu \mathrm{m}^{3}\right)$.

proposed that only when other more suitable resources are almost completely depleted does the microzooplankton shift its diet from nano-sized prey to bacteria. These environmental conditions are more common in oligotrophic than eutrophic systems such as the eastern part of Kaštela Bay. Rassoulzadegan et al. (1988) observed that ciliates smaller than $30 \mu \mathrm{m}$ consumed $72 \%$ of picoplankton and $28 \%$ of nanoplankton, whereas for $30-50 \mu \mathrm{m}$ ciliates, the proportions were reversed. These results explain why we found a more significant correlation between NLC II and HNF than between NLC II and bacteria. The schematic review of immediate connections among the investigated parameters, based on statistical analyses, is shown in Figure 9.

During the colder part of the year, the coupling between bacteria and HNF is very weak and bacterial abundance is mainly controlled by resource supply, whereas HNF abundance is regulated by microzooplankton grazing (Gasol et al., 1995; Šolić and Krstulović, 1994, 1995; Šolić et al., 1998). A similar situation was noticed in the eutrophicated part of Kaštela Bay in September 1998, April and October 1999 (Fig. 8). We can conclude that top-down control by ciliated protozoa during the colder months was a regular occurrence in the bay. However, the high impact of ciliates in summer 1998 could be a sporadic phenomenon, influenced by the changed taxonomic composition of the phytoplankton assem- 
blage, as well as the higher eutrophication level of the study area. However, this area requires further research in order to verify this assertion.

From the high densities of HNF and ciliated protozoa present in the eutrophicated part of Kaštela Bay, we can conclude that significant amounts of bacterial production could be transferred to higher trophic levels through the microbial food web. In fact, we have established a clear relationship between bacterial production and HNF biomass. In addition, NLC I and NLC II had a positive and significant correlation with HNF. Ciliates probably limited the growth of HNF indirectly as they competed for bacteria and by direct grazing on HNF. However, the type of regulation mechanism depends on NLC size structure (Rassoulzadegan et al., 1988). The size of the ciliate assemblages has been related to the trophic status of the water, with small organisms dominating in eutrophic conditions (Urrutxurtu et al., 2003). Absence of significant relations among TIN and the biotic parameters studied suggests the importance of knowing the TIN taxonomic composition. For example, Helicostomella subulata and Codonellopsis schabi with maximal abundances of 3975 ind. $1^{-1}$ (April 1999) and 2963 ind. $\mathrm{l}^{-1}$ (September 1998), could be considered as important factors of top-down control. The basic food source for TIN generally consists in nanoflagellates, but autotrophic picoplankton can sometimes represent their complementary diet (Bernard and Rassoulzadegan, 1993). With their relatively large size and high metabolic rates (Capriulo and Carpenter, 1980; Verity, 1986) TIN appear to be able to shunt the production from the microbial food web to higher trophic levels (Bernard and Rassoulzadegan, 1993). However, predation by copepod nauplii on ciliates and carbon transfer to higher trophic levels could be of relative importance only in the period when they are most abundant. Certainly, further research about the efficiency of carbon transfer, on a temporal as well as spatial scale, is needed to obtain a better understanding of the trophic relationships inside the microbial community.

\section{ACKNOWLEDGEMENTS}

We are grateful to the crew and technicians of the $\mathrm{R} / \mathrm{V}$ "Bios" for their assistance during the cruises. The comments of the referees are greatly appreciated. This study was supported by the Ministry of Science, Education and Sport of the Republic of
Croatia as a part of the research program: "Structural and trophic relations in the Adriatic Sea pelagic ecosystem".

\section{REFERENCES}

Beers, J.R. and G.L. Stewart. - 1970. Numerical abundance and estimated biomass of microzooplankton. Bull. Scripps Inst. Oceanogr., 17: 67-87.

Bernard, C. and F. Rassoulzadegan. - 1993. The role of picoplankton (cyanobacteria and plastidic picoflagellates) in the diet of tintinnids. J. Plankton Res., 15: 361-373.

Bojanić, N. - 2001. Seasonal distribution of the ciliated protozoa in Kaštela Bay. J. Mar. Biol. Ass. U.K., 81: 383-390.

Bojanić, N., M. Šolić, N. Krstulović, I. Marasović, Ž. Ninčević and O. Vidjak. - 2001. Seasonal and vertical distribution of the ciliated protozoa and micrometazoa in Kaštela Bay (central Adriatic). Helgol. Mar. Res., 55: 150-159.

Bojanić, N., M. Šolić, N. Krstulović, S. Šestanović, I. Marasović and Ž. Ninčević. - 2005. Temporal variability in abundance and biomass of ciliates and copepods in the eutrophicated part of Kaštela Bay (Middle Adriatic Sea). Helgol. Mar. Res., 59: 107-120.

Borsheim, K.Y. and G. Bratbak. - 1987. Cell volume to cell carbon conversion factors for a bacteriovorous Monas sp. enriched from seawater. Mar. Ecol. Prog. Ser., 36: 171-175.

Bratbak, G. and I. Dundas. - 1984. Bacterial dry matter content and biomass estimations. Appl. Environ. Microbiol., 48: 755-757.

Capriulo, G.M. and E.J. Carpenter. - 1980. Grazing by 35 to $202 \mu \mathrm{m}$ micro-zooplankton in the Long Sound. Mar. Biol., 56: 319-326.

Conover, R.J. - 1982. Interrelations between microzooplankton and other plankton organisms. Ann. Inst. Océanogr. Paris. 58: 31-46.

Dolan, J.R. and C.L. Gallegos. - 1991. Trophic coupling of rotifers, microflagellates and bacteria during fall months in the Rhode River estuary. Mar. Ecol. Prog. Ser., 77: 147-156.

Ducklow, H.W. - 1992. Factors regulating bottom-up control of bacterial biomass in open ocean communities. Arch. Hydrobiol. Beih., 37: 207-217.

Edler, L. - 1979. Recommendations on methods for marine biological studies in the Baltic Sea. Phytoplankton and chlorophyll. The Baltic marine biologists working group 5: 1-38.

Fonda Umani, S. and A. Beran. - 2003. Seasonal variations in the dynamics of microbial plankton communities: first estimates from experiments in the Gulf of Trieste, Northern Adriatic Sea. Mar. Ecol. Prog. Ser., 247: 1-16.

Fuhrman, J.A. and F. Azam. - 1982. Thymidine incorporation as a measure of heterotrophic bacterioplankton production in marine surface waters: evaluation and field results. Mar. Biol., 6: $109-120$.

Fuks, D. - 1995. Uloga bakterioplanktona u ekosustavu sjevernog Jadrana. Ph. D. thesis, Univ. of Zagreb.

Gasol, J.M. and D. Vaqué. - 1993. Lack of coupling between heterotrophic nanoflagellates and bacteria: a general phenomenon across aquatic systems? Limnol. Oceanogr., 38: 657-665.

Gasol, J.M., A.M. Simones and J. Kalff. - 1995. Patterns in the topdown versus bottom-up regulation of heterotrophic nanoflagellates in temperate lakes. J. Plankton Res., 17: 1879-1903.

Haas, L.W. - 1982. Improved epifluorescence microscopy for observing planktonic micro-organisms. Ann. Inst. Océanogr. Paris. 58: 261-266.

Hagström, A., F. Azam, A. Andersson, J Wikner and F. Rassoulzadegan. - 1988. Microbial loop in an oligotrophic pelagic marine ecosystem: possible roles of cyanobacteria and nanoflagellates in the organic fluxes. Mar. Ecol. Prog. Ser., 49: 171-178.

Hobbie, J.E., R.J. Daley and S. Jasper. - 1977. Use of nucleopore filters for counting bacteria by fluorescence microscopy. App. Environ. Microbiol., 33: 1225-1228.

Kivi, K., H. Kuosa and S. Tanskanen. - 1996. An experimental study on the role of crustacean and microzooplankton grazers in the planktonic food web. Mar. Ecol. Prog. Ser., 136: 59-68.

Krstulović, N., M. Šolić and I. Marasović. - 1997. Relationship between bacteria, phytoplankton and heterotrophic nanoflagel- 
lates along the trophic gradient. Helgol. Meeresunters., 54: 433-443.

Leakey, R.J.G., P.H. Burkill and M.A. Sleigh. - 1994. A comparison of fixatives for the estimation of abundance and biovolume of marine planktonic ciliate populations. J. Plankton Res., 16: 375-389.

Marasović, I. and I. Vukadin. - 1982. "Red tide" in the Vranjic basin (Kaštela Bay). Bilješke-Notes, 48: 1-7.

Marasović, I. and T. Pucher-Petković. - 1991. Eutrophication impact on the species composition in a natural phytoplankton community. Acta Adriat., 32: 719-729.

Monti, M. and S. Fonda Umani. - 1999. Distribution of the main microzooplankton taxa in the Ross Sea (Antartica): Austral summer 1994. In: F. Faranda, L. Guglielmo and A. Ianora (eds.), Ross Sea ecology - ItaliAntartide expeditions 19871995, pp. 275-289. Springer - Verlag, Heidelberg.

Paffenhöfer, G.A. - 1998. Heterotrophic protozoa and small metazoa: feeding rates and prey-consumer interactions. J. Plankton Res., 20: 121-133.

Pitta, P., A. Giannakourou, P. Divanach and M. Kentouri. - 1998. Planktonic food web in marine mesocosm in the Eastern Mediterranean: bottom-up or top-down regulation? Hydrobiologia, 363: 97-105.

Putt, M. and D.K. Stoecker. - 1989. An experimentally determined carbon:volume ratio for marine 'oligotrichous' ciliates from estuarine and coastal waters. Limnol. Oceanogr., 34: 1097-1103.

Rassoulzadegan, F., M. Lavel-Peuto and R.W. Sheldon. - 1988. Partitioning of the food ration between pico- and nanoplankton. Hydrobiologia, 159: 75-88.

Riemann, B., P.K. Bjørnsen, S. Newell and R. Fallon. - 1987. Calculation od cell production of coastal marine bacteria based on measured incorporation of $\left({ }^{3} \mathrm{H}\right)$ thymidine. Limnol. Oceanogr. 32: 471-476.

Rodríguez, F., E. Fernández, R.N. Head, D.S. Harbour, G. Bratbak, M. Heldal and R. P. Harris. - 2000. Temporal variability of viruses, bacteria, phytoplankton and zooplankton in the western English Channel off Plymouth. J. Mar. Biol. Ass. U.K., 80: 575-586.

Ruttner-Kolisko, A. - 1977. Suggestions for biomass calculations of plankton rotifers. Arch. Hydrobiol. Beih. Ergebn. Limnol., 8: 71-76.

Sanders, R.W., K.G. Porter, S.J. Bennett and A.E. DeBiase. - 1989. Seasonal patterns of bacterivory by flagellates, ciliates, rotifers, and cladocerans in a freshwater planktonic community. Limnol. Oceanogr. 34: 673-687.

Sanders, R.W., D.A. Caron and U.G. Berninger. - 1992. Relationship between bacteria and heterotrophic nanoplankton in marine and fresh waters: an inter-ecosystem comparison. Mar. Ecol. Prog. Ser., 86: 1-14.

Sherr, E.B. and B.F. Sherr. - 2002. Significance of predation by protists in aquatic microbial food webs. Antonie Leeuwenhoek, 81: 293-308.

Strickland, J.D.H. and T.R. Parsons. - 1972. A practical handbook of seawater analysis. Bull. Fish. Res. Bd. Can., 167: 1-310.

Šolić, M. and N. Krstulović. - 1994. The role of predation in controlling bacterial and heterotrophic nanoflagellate standing stocks in the coastal Adriatic Sea: seasonal patterns. Mar. Ecol. Prog. Ser., 144: 219-235.

Šolić, M. and N. Krstulović, - 1995. Bacterial carbon flux through the microbial loop in Kaštela Bay (Adriatic Sea). Ophelia, 41: 345-360.

Šolić, M., N. Krstulović, N. Bojanić, I. Marasović and Ž. Ninčević. - 1998. Seasonal switching between relative importance of bottom-up and top-down control of bacterial and heterotrophic nanoflagellate abundance. J. Mar. Biol. Ass. U.K., 78: 755-766.

Thingstad, T.F. and F. Rassoulzadegan. - 1995. Nutrient limitation, microbial food webs, and biological 'C-pumps': suggested interactions in P-limited Mediterranean. Mar. Ecol. Prog. Ser., 29: $105-115$.

Urrutxurtu, I., E. Orive and A. Sota. - 2003. Seasonal dynamics of ciliated protozoa and their potential food in an eutrophic estuary (Bay of Biscay). Estuar. Coast. Shelf Sci., 57: 1169-1182.

Utermöhl, H. - 1958. Zur Vervollkommnung der quantitativen Phytoplankton - Methodik. Mitt. Int. Ver. Theor. Angew. Limnol., 9: 1-37.

Verity, P.G. - 1986. Grazing of phototrophic nanoplankton by microzooplankton in Narragansett Bay. Mar. Ecol. Prog. Ser., 117: 299-306

Verity, P.G. and C. Langdon. - 1984. Relationships between lorica volume, carbon, nitrogen and ATP content of tintinnids in Narragansett Bay. J. Plankton Res., 6: 859-868.

Verity, P.G. and V. Smetacek. - 1996. Organism life cycles, predation and the structure of marine pelagic ecosystems. Mar. Ecol. Prog. Ser., 130: 277-293.

Weisse, T. - 1991. The annual cycle of heterotrophic freshwater nanoflagellates: role of bottom-up versus top-down control. $J$. Plankton Res., 13: 167-185.

Zore-Armanda, M. - 1980. Some dynamic and hydrographic properties of the Kaštela Bay. Acta Adriat., 21: 55-74.

Scient. ed.: D. Vaqué

Received June 29, 2005. Accepted March 15, 2006.

Published online July 6, 2006. 